\title{
SCIENTIFIC REP RTS \\ OPEN Author Correction: Essential oils sensory quality and their bioactivity against the mosquito Aedes albopictus
}

\section{S. Bedini ${ }^{1}$, G. Flamini ${ }^{2}$, R. Ascrizzi ${ }^{2}$, F. Venturi ${ }^{1}$, G. Ferroni ${ }^{1}$, A. Bader ${ }^{3}$, J. Girardi ${ }^{1}$ \& B. Conti $\mathbb{D}^{1}$}

Correction to: Scientific Reports https://doi.org/10.1038/s41598-018-36158-w, published online 14 December 2018

The Acknowledgements section in this Article is incomplete.

"The authors wish to thank Mr. Paolo Giannotti for the technical assistance, the panelists and the volunteers who participated to the repellence tests."

should read:

"The authors wish to thank Mr. Paolo Giannotti for the technical assistance, the panelists and the volunteers who participated to the repellence tests. This research was supported by Italian Ministry of Education, University and Research (MIUR) (PRIN Project 2015 “BIOPIC", 2015 BABFCF)."

(i) Open Access This article is licensed under a Creative Commons Attribution 4.0 International License, which permits use, sharing, adaptation, distribution and reproduction in any medium or format, as long as you give appropriate credit to the original author(s) and the source, provide a link to the Creative Commons license, and indicate if changes were made. The images or other third party material in this article are included in the article's Creative Commons license, unless indicated otherwise in a credit line to the material. If material is not included in the article's Creative Commons license and your intended use is not permitted by statutory regulation or exceeds the permitted use, you will need to obtain permission directly from the copyright holder. To view a copy of this license, visit http://creativecommons.org/licenses/by/4.0/.

(C) The Author(s) 2019 